\title{
INTELLECTUAL PROPERTY'S TERRITORIAL FRAMEWORK AND THE MACRO-LEVEL CONTRADICTION WITH TAX POLICY
}

\section{Susy Frankel*}

\begin{abstract}
Many large intellectual property owning firms have not paid "fair taxes" in the territories where they achieve sales and licences of their products. Rather, they tend to utilise regimes where they pay as little tax as possible. The international taxation system has allowed this to happen extensively. This is currently under challenge from some governments and the OECD. In this tribute to renowned tax scholar, John Prebble, the territorial nature of intellectual property is explained. Territoriality is a key organising principle of the existence of intellectual property rights, their exploitation and enforcement. At a high-level the territorial nature of intellectual property is not consistent with what happens to the profits of its exploitation, rather at a macro-level the frameworks of the international intellectual property regime and the international tax regimes are in contradiction.
\end{abstract}

\section{INTRODUCTION}

The international intellectual property system relies on territoriality as one of its key organising principles. The legal mechanisms that achieve this are, perhaps obviously, local statutes and case law. Less obviously, the details of those laws either reflect the minimum standards of protection that are required in each member territory of international intellectual property agreements or a standard above those minimum requirements. More extensive protection is often the approach in developed country economies. ${ }^{1}$ This mechanism of minimum standards is not the most common type of framework found

* FRSNZ, Professor of Law, Victoria University of Wellington | Te Herenga Waka. Congratulations to Emeritus Professor John Prebble. I offer this modest contribution in his honour. I draw on my own research about the effects of territoriality in intellectual property to explain what I conclude is a macro-level contradiction with tax policy.

1 The TRIPS Agreement allows for countries to provide for protection that is more extensive than the standards in the agreement; Agreement on Trade-Related Aspects of Intellectual Property Rights, Marrakesh Agreement Establishing the World Trade Organization, Annex 1C, 1869 UNTS 299 (signed 15 April 1994, entered into 
in international agreements. Indeed, it is the only agreement structured in that way, among World Trade Organization (WTO) agreements. ${ }^{2}$ Part of the design and function of minimum standards, as an international framework mechanism, is to reinforce the territorial nature of intellectual property law.

Also, enforcement of intellectual property is territorial whether that enforcement is civil or criminal. ${ }^{3}$ While a person can usually only be tried in the place where a crime took place, civil law actions differ. Many private law actions can be brought in foreign courts, provided there is some connection to the relevant forum. If a person wishes to sue another for intellectual property infringement, such as patent infringement, however, then the jurisdiction where the case takes place must be where the patent was registered. ${ }^{4}$ This may mean that cases on similar subject matter that are brought in more than one jurisdiction cannot be joined and heard together before one court. There is some flexibility around this territorially-limited jurisdiction-related concept for unregistered intellectual property rights, particularly for copyright disputes. Even if, however, in limited circumstances a court can hear a foreign copyright infringement, territoriality remains prominent as the law applied to that dispute is territorial. ${ }^{5}$ Depending on the circumstances, it could be either the foreign law or the forum law. ${ }^{6}$

Whether copyright, patent or any other intellectual property rights, the owner of those interests will have several exclusive rights, such as a right to reproduction and communication to the public of a copyright work. ${ }^{7}$ In practice, territoriality means that each intellectual property exclusive right can

force 1 January 1995) [TRIPS Agreement], art 1. This approach is also found in other international intellectual property agreements.

2 The WTO agreements are one agreement with several parts.

3 The territorial nature of criminal infringement, as applied to intellectual property infringement, is exemplified in the extradition proceedings brought against Kim Dotcom and others involved in the Megaupload companies: Ortmann v United States of America [2020] NZSC 120, [2020] 1 NZLR 475.

4 Potter v Broken Hill Pty Co Ltd (1906) 3 CLR 479 (HCA). See also Regulation (EU) 1215/2012 of the European Parliament and of the Council on Jurisdiction and the Recognition and Enforcement of Judgments in Civil and Commercial Matters [2012] OJ L351, formerly the Brussels Convention on Jurisdiction and the Enforcement of Judgments in Civil and Commercial Matters 1659 UNTS 202 (signed 27 September 1973, entered into force 1 February 1973), arts 2 and 16.

5 Pearce v Ove Arup Partnership Ltd [2000] Ch 403. See discussion in Susy Frankel Intellectual Property in New Zealand (2nd ed, Lexis Nexis Wellington, 2011) at [2.3.3].

6 Some courts have applied foreign law for ownership but local law for infringement, see for example Itar-Tass Russian News Agency v Russian Kurier Inc 153 F 3d 82 (2nd circuit1998), (1998) 43 IPR 565. New Zealand courts have only applied local law for all aspects of such disputes, see Kabushiki Kaisha Sony Computer Entertainment (t/a Sony Computer Entertainment Inc) v Van Veen (2009) 19 PRNZ 836 (HC). See also discussion in Frankel, above n 5, at [2.3.5].

7 Copyright Act 1994 (NZ), s 16. 
be owned or licensed to separate entities in different jurisdictions. So, for example, the owner of copyright in a novel may license a publisher, based in one place, with some rights to distribute the novel in that place, and perhaps also in other places, but not necessarily globally. The same owner can also license another publisher elsewhere. Licensing might extend to a film company to produce a film from the novel in one of the same places, or even another place, and the distribution rights from that film can be licensed to various entities. To make the film, there will likely also be licences for the use of other rights, such as sound recordings. These examples are illustrative of a wider picture often involving multiple licensing agreements. The value of intellectual property is often realised through a web of licensing arrangements. There is seemingly no limit to the complexity of these arrangements but underpinning them all is the territorial nature of intellectual property rights. That territoriality gives power to rights owners to exploit different rights in multiple markets, enabling maximisation of global profits. Further, what is available in one market may not be the same as another market and the owner of the revenue may also be different. The international tax system has not been constrained by this kind of territoriality, so the same businesses that maximise exploitation of rights through the territorial model minimise the payment of taxes in those territories. This can be done in a variety of ways that might, for example, utilise holding companies that own intellectual property so that royalties earned around the world are collected predominantly in one place. Those holding companies are frequently located in tax havens, including the Cayman Islands and Delaware, for example.

The tools to address the outflow of royalties, when combined with the non-payment of local tax, are developing but have not yet overcome this problem. This problem is especially prevalent with the large tech companies. Some jurisdictions have tried to prevent some outflows of royalties and other tax benefits. In 2016 the European Commission held that Ireland granted Apple "undue tax benefits" of up to $€ 12$ million. ${ }^{8}$ The Court of Justice of the European Union overruled this on the basis that the Commission was not able to show that Apple was granted "an illegal advantage". 9 The matter is under appeal.

In order to address "fair tax" issues, including more broadly than relating to intellectual property, in 2020 the OECD announced its plan to move towards a global agreement where "fair tax" is paid. ${ }^{10}$ Paying taxes in the territory where the intellectual property earns money is far from being a uniform principle, or indeed the requirement to pay locally is not uniformly applied. It probably applies to the small intellectual property owner, but almost certainly does not apply to large multinational intellectual property industries. This phenomenon has become well-known with digital companies

8 European Commission "State aid: Ireland gave illegal tax benefits to Apple worth up to $€ 13$ billion" (30 Aug 2016) <https://ec.europa.eu>.

9 Simon Van Dorpe "EU Court annuls €13B Irish tax bill for Apple" (15 July 2020) Politico < www.politico.eu>.

10 OECD "Ensuring multinationals pay a fair share of taxes" <www.oecd.org>. 
(such as Google, Facebook and Apple) but it is much more widespread and extends to companies with hard products, such as GoreTex. ${ }^{11}$

There is a gaping contradiction between the policies of the extreme territoriality of intellectual property rights, particularly when they are used globally, and the taxation system. Given that they are separate regimes they have separate rationales and much distinct jurisprudence, which explains their different approaches. But the rise of multinational intellectual property businesses has highlighted this inconsistency, raising concerns about how to pay fair tax. This article does not directly tackle that issue but rather illuminates the ways in which territorial rights of intellectual property, and the policies behind them, lend support to the ability of intellectual property owning companies to not pay fair tax. This supporting role of territoriality may be an unintended consequence of intellectual property law's design. The territoriality of intellectual property has positive goals as well as negative consequences. This article highlights the high-level policy contradiction by explaining the territorial nature of intellectual property that has paved the way for this inequality in paying tax to flourish.

Part II of this article explains how territoriality works in the international intellectual property system, including a discussion of using territoriality to maximise prices in foreign markets. Part III explains some of the inroads into territoriality that have taken place in intellectual property law but have not caused the overall territorial structure to change. Part IV concludes that there are both good and bad reasons for intellectual property law's territoriality, but that when it is placed against income flows and the tax system there is a macro-level contradiction in the global policy of intellectual property protection.

\section{TERRITORIALITY IN INTERNATIONAL INTELLECTUAL PROPERTY}

The concept of territoriality pervades intellectual property law and has a variety of meanings and effects, including the geographical scope of both registered and unregistered rights and the ability to enforce those rights. For registered intellectual property rights (trade marks, patents and designs), registration in one country gives protection in that country and not in other places. If a business, for example, wishes to have a registered trade mark in each of Australia and New Zealand it must apply to register the trade mark in each jurisdiction. And if it is successful, each registration is independent of the other. An exception to this is in the European Union, where there is a community trade mark (discussed below). As yet, there is no equivalent regional arrangement for patents which are arguably the most territorial of intellectual property rights. The European Commission has, for some time, been

11 Jeffrey A Maine and Xuan-Thao Nguyen The Intellectual Property Holding Company, Tax US and Abuse from Victoria's Secret to Apple (Cambridge University Press, Cambridge, 2017). 
working on a unitary patent registration and unitary patent court. ${ }^{12}$ The completion of that endeavour has been made more difficult because of Brexit. ${ }^{13}$

Registration gives a form of property right that is both granted and administered by individual states. As only the relevant state can give such a grant and, as states are territorial, the nature of the rights as territorial are reinforced. This territoriality principle applies even where rights, most significantly copyright, are not subject to mandatory registration. ${ }^{14}$ Copyright owners have different copyright interests and independent sets of rights in each jurisdiction. This is not primarily achieved through independence of registration but rather the international intellectual property agreements reinforce this territoriality. The Berne Convention, which governs copyright, for example, provides "the extent of protection ... shall be governed exclusively by the laws of the country where protection is claimed". 15

The territorial rules of registration and enforcement allow owners to segment markets and exploit them as individual units. The most obvious effect of this sort of market segmentation is the ability of intellectual property owners to charge different prices in different markets. Also, separate markets may have products of differing quality in each of those markets. One litigated example relates to toothpaste which had varying additive and fluoride content in different markets. ${ }^{16}$ The territorial effects of intellectual property can be used to keep products destined for one market out of another market. Rights owners who use territoriality for differential pricing (or maintaining different characteristics or qualities of goods) usually aim to stop the cheaper products entering the market where products are available at a higher price. Countries can do this by preventing parallel importing.

One of the more controversial issues in international intellectual property is whether products can be parallel imported from separate markets, and this issue is even more controversial when it comes to digital products. A parallel import is an import where there is a similar, but independent, intellectual property right in the import market to a right where the product has been exported from. The rights may be, but are not necessarily, owned by the same owner. Market segmentation based on territoriality allows countries to prevent parallel imports. If the owner or exclusive licensee of the right in both territories is not the same this can incentivise parallel imports. And where the prices at which the

12 European Commission "Unitary Patent" Internal Market, Industry, Entrepreneurship and SMEs $<$ https://ec.europa.eu>.

13 Mark Bell "UK: Unitary Patent System Back on Track?" (3 December 2020) mondaq <www.mondaq.com>.

14 The Berne Convention requires no formalities for copyright to exist. This is widely interpreted as meaning no registration. Berne Convention for the Protection of Literary and Artistic Works 828 UNTS 221 (Revised 1971) (opened for signature 9 September 1886, entered into force 5 December 1887) [Berne], art 5(2).

15 Article 5(2)

16 Colgate Palmolive Ltd v Markwell Finance Ltd [1989] RPC 497 (CA). 
goods are sold are different, there is an incentive for export from the low cost market to a higher priced market.

There are different rationales and related narratives used to justify parallel importing, or to justify a ban on parallel imports. One rationale for allowing parallel importing is that it is a way to provide goods where they are not otherwise available, or where they are available but the parallel import will be cheaper. Many intellectual property owners try to prevent this happening through various arrangements, such as exclusive distribution rights. Parallel importing can overcome such arrangements, but parallel importing is not always practical. Looked at from a perspective other than price, the ability to allow parallel imports may also increase access to technology and knowledge assets, which in turn can lead to innovation and development. ${ }^{17}$ Some rights owners argue that they need to divide markets in order to recoup their investment in creating works and inventions, but this is not supported by objective evidence. To be supported the owners would need to reveal detail of their R\&D costs and those are usually treated as commercially secret. Additionally, the results of territoriality have often led to the only availability, in export markets, being high-priced products and the price being unaffordable (mostly in developing countries). For this to occur, there are likely the relevant rights in the export market, preventing third party manufacture. This combination of high prices for imports and foreign owned rights can suppress local innovation and result in these markets not being supplied. This is particularly a problem with pharmaceuticals and goods which involve technology that is complex, especially where it is not amenable to reverse engineering and requires skills and capacity that are not easily replicated.

There is no enforceable international agreement on the parameters of parallel importation. The Agreement that regulates the trade of intellectual property across borders, the Agreement on TradeRelated Aspects of Intellectual Property Rights (TRIPS Agreement), part of the WTO Agreement, allows for different approaches to parallel importing. ${ }^{18}$ Although the TRIPS Agreement provides that a patent owner has the exclusive right to control imports of a patented product or processes, ${ }^{19}$ there are no import rights relating to other types of intellectual property. In any event, the TRIPS Agreement also provides that no disputes may be brought in relation to exhaustion of rights. ${ }^{20}$ In this way, members of the WTO can use the prevention of parallel imports as a legitimate trade barrier. In effect, the WTO has allowed this use of the territoriality of intellectual property rights, even though it creates trade barriers, to be tolerated as some kind of exception to the free movement of goods principle

17 See generally Neil W Netanel (ed) The Development Agenda: Global Intellectual Property and Developing Countries (Oxford University Press, Oxford, 2008).

18 The TRIPS Agreement is not a standalone agreement. It is part of the WTO Agreements which are a single package of agreements to which all members must belong and there can be no reservations.

19 TRIPS Agreement, above n 1, art 28.

20 Article 6 
enshrined in the General Agreement on Tariffs and Trade (GATT). ${ }^{21}$ When it comes to digital goods these artificial walls are broken down, as Part III discusses. As far as pharmaceuticals are concerned, there are detailed rules allowing limited parallel imports relating to products manufactured under compulsory licence. ${ }^{22}$

The absence of any global rules on parallel importing is not an omission, rather it has arisen because of diverse views that tend to reflect differing economic policies and needs. Broadly, parallel importing may be more common, if not necessary, in many developing countries. Also, many developed countries allow some parallel importing. ${ }^{23}$ No consistency is found. Some countries, such as New Zealand, allow parallel imports of copyright goods and related trade marks, but not patented goods. Other small countries, such as Singapore, allow parallel imports of pharmaceuticals in some circumstances. $^{24}$ The predominant rationale in a small market economy to allow some parallel importing is to introduce competition into an otherwise potentially non-competitive market. The history of parallel importing opening up in New Zealand was driven by the import of second-hand cars. $^{25}$ As I have stated elsewhere: ${ }^{26}$

There are also three compelling rationales to allow parallel importing: first, to obtain cheaper goods by importing them from a market where they are sold at a lower price; second, to introduce competition into an otherwise non-competitive market, which should also exert a downward pressure on price; third, a country might want to compare and expand the range of available products and their varying qualities if only a limited range is locally available. These rationales are easily and directly linked to consumer welfare narratives.

21 General Agreement on Tariffs and Trade 1994, Marrakesh Agreement Establishing the World Trade Organization (WTO Agreement), Annex 1A, 1867 UNTS 187 (signed 15 April 1994, entered into force 1 January 1995), art XX. See discussion in Susy Frankel "The Applicability of GATT Jurisprudence to the Interpretation of the TRIPS Agreement" in Carlos M Correa (ed) Research Handbook on the Interpretation and Enforcement of Intellectual Property Under WTO Rules (Edward Elgar Publishing, Cheltenham, 2010) at 3-23.

22 TRIPS Agreement, above n 1, art 31.

23 Susy Frankel and Daniel Gervais "International Intellectual Property Rules and Parallel Imports" in Irene Calboli and Edward Lee (eds) Research Handbook on Intellectual Property Exhaustion and Parallel Imports (Edward Elgar Publishing, 2016) at 85-105.

24 Susy Frankel Test Tubes for Global Intellectual Property Issues: Small Market Economies (Cambridge University Press, Cambridge, 2015) at chapter 8.

25 See Susy Frankel "A Brief Perspective: The History of Copyright in New Zealand" in Brian Fitzgerald and Benedict Atkinson (eds) Copyright Future Copyright Freedom (Sydney University Press, Sydney, 2011) at $72-78$.

26 Frankel and Gervais, above $n$ 23, at 87-88. 
When it comes to goods, the mechanisms used to prevent parallel importing depend on customs barriers and litigation. These come with their own challenges. ${ }^{27}$ In the digital world such market segmentation is comparatively difficult. Attempts to separate markets online are achieved by online stores only selling to certain jurisdictions and online digital services providing local services. Technological means are used to separate regions. In some instances, these technological barriers can be defeated by technological means, such as virtual private networks (known as VPNs). However, some copyright laws protect technological protection mechanisms (TPMs) in their own right, which means that certain sorts of circumvention of TPMs can amount to an infringement. ${ }^{28}$

This territorial nature of intellectual property rights also applies to enforcement. The setting of international intellectual property minimum standards arises from international agreements, which are instruments of public international law. The TRIPS Agreement requires that its members provide for minimum standards of enforcement, but it does not have rules either about which courts can have jurisdiction over intellectual property disputes involving parties from two or more different countries or what law a court should apply in such disputes. These aspects of enforcement (jurisdiction and choice of law) are determined by rules of private international law, which are predominantly national and sometimes regional rules. There is no international intellectual property agreement that comprehensively addresses these private international law matters.

As they are national laws, and particularly as there is little international agreement about them, private international law rules vary among countries. In many jurisdictions, if the validity of a registered right (such as a patent or a trade mark) is contested, then only the court in the territory that granted that right could hear any claim about the validity of the right. ${ }^{29}$ In contrast, some courts will hear foreign infringement claims, but this can be complicated if validity of the registration is raised in defence of infringement. Most countries would then apply the rule that only the court in the territory where the right was granted can hear the dispute. ${ }^{30}$ For a long time the same territorial principle applied to infringement of copyright, but as discussed in the next part, some courts will hear foreign infringement of copyright cases. Choice of law is another matter.

Many instances of territoriality give rise to certain small exceptions. The very existence of permitted parallel importing might also be seen as an inroad into territoriality, but it is a little different

27 Enforcing intellectual property rights at the border can create difficult issues as to proof and how customs officials might assess such matters. In New Zealand challenging such border incursions can involve the owner carrying the burden of filing notices and related proof. See for example Copyright Act, ss 135-136.

28 Copyright Act, ss $226 \mathrm{~A}$ to $226 \mathrm{E}$, for example. The international obligation to protect TPMs is found in World Intellectual Property Organization Copyright Treaty 2186 UNTS 121 (signed 20 December 1996, entered into force 6 March 2002) [WCT].

29 See for example Regulation (EU) 1215/2012, above n 4 ; and Potter, above n 9.

30 Fort Dodge Animal Health Limited v AKZO Nobel NV [1998] FSR 222 (CA). See also Atkinson Footwear Ltd $v$ Hodgskin International Services Ltd (1994) 31 IPR 186 (NZHC). 
from other inroads. With parallel importing, the intellectual property rights remain much the same (registration does not change), even if the result of such importing is that there can be more than one owner's products available in a market. Other inroads discussed in the next part are directed to the scope of rights.

\section{INROADS TO TERRITORIALITY}

For several reasons, territoriality is not impervious. If, for example, a business wishes to have a registered trade mark in multiple territories, then there is an international system to facilitate that, known as the Madrid system. ${ }^{31}$ In essence, the system uses a central application to facilitate global applications among trade mark registration offices. This creates a kind of network among trade mark offices. This facilitation does not remove the need for separate territorial registrations. In other words, this kind of global facilitation is part of a system grounded on territoriality. Alongside this facilitation network, the international agreements also emphasise the independence of each territorially registered right. $^{32}$

The rigours of territoriality are softened by rules requiring that if a trade mark is registered in one place, then that has two important effects: a right of priority of the first registration ${ }^{33}$ and that subsequent trade mark offices accept applications "as is" (also known as the telle quelle rule). ${ }^{34}$ The priority rule means that the same registration can be secured in foreign countries as well as the first place of registration. The telle quelle rule provides that a trade mark "duly registered in the country of origin shall be accepted for filing and protected as is in the other countries of the Union. ${ }^{135}$ On the face of it, this rule looks like a considerable territorial incursion that requires one trade mark office to follow, without question, the registration in another office. However, this rule is often less of a territorial incursion if it is treated as applying to the form of a mark, rather than its substance. The rule also comes with exceptions, such as if the relevant application is not distinctive or conflicts with an earlier registration. ${ }^{36}$

31 Madrid Agreement Concerning the International Registration of Marks 1981828 UNTS 390 (as revised at Stockholm 14 July 1967, entered into force 1 April 1996) and Protocol Relating to the Madrid Agreement Concerning the International Registration of Marks 1989 (signed 27 June 1989, entered into force 1 December 1995).

32 Paris Convention for the Protection of Industrial Property 828 UNTS 305 (as amended on 28 September 1979, entered into force 3 June 1984) [Paris Convention], art 6.3.

33 Article 4.

34 Article 6 of the 1883 text, now found in Article 6 quinquies of the latest Act of the Paris Convention, above n 32 .

35 Article 6 quinquies A [emphasis added].

36 Article 6 quinquies $\mathrm{B}$. 
As global commerce has developed and grown, the international system started to address issues of protecting unregistered trade marks in foreign jurisdictions. It did this primarily by increasing territorial rights rather than introducing some sort of extraterritoriality of those existing territorial rights. The relevant starting point was the creation of an international agreement obliging members to provide effective protection against unfair competition that was introduced into the Paris Convention in $1900 .{ }^{37}$ This meant that each territory had to protect against unfair competition, even of foreignowned rights. An additional overlay of territoriality was to leave much latitude for countries to decide how they would define the rights to protect against unfair competition. In New Zealand, this obligation is now met through both the common law doctrine of passing off and the Fair Trading Act 1986.

From 1925 the international agreements introduced the requirement of providing a minimum level of protection for "well-known" marks. This protection was both against infringement and when third parties sought to use or register conflicting marks. ${ }^{38}$ What is meant by "well-known" has continued to be debated, particularly as the perceived need for protection of goodwill has increased following the rise of international trade in trade marked goods and services, regardless of whether the marks are registered. Disputes tend to focus on the degree of reputation required in the territory in which protection was sought, but common law jurisdictions have not approached this uniformly. In Australia, the extent of reputation required to establish passing off is not necessarily significant and does not require actual trade in Australia, but some advertising or spillover reputation will suffice. ${ }^{39}$ In ConAgra Inc v McCain Foods, for example, it was sufficient that the plaintiff's brand "Healthy Choice" was known to travelling Australians, even though it was not available for purchase in Australia. ${ }^{40}$ In the United Kingdom there has been some strengthening of this approach to passing off. The Supreme Court has required that actual customers purchasing the relevant products or services are based in the United Kingdom market. ${ }^{41}$

New Zealand has tended to take an approach somewhere in between the two differing approaches of the United Kingdom and Australia. To succeed in passing off, the New Zealand courts have required that the plaintiff establish that it has a reasonable degree of reputation, but no New Zealand case has yet gone as far as that in the United Kingdom of definitively requiring local customers. In some circumstances, local customers may purchase goods and services over the internet. Such sales

37 Article 10 bis.

38 Article 6 bis.

39 ConAgra Inc v McCain Foods (Aust) Pty Ltd [1992] 33 FCR 302 (FCA).

40 ConAgra Inc v McCain Foods (Aust) Pty Ltd, above n 39.

41 Starbucks (HK) Limited v British Sky Broadcasting Group Plc [2015] UKSC 31. See also Olivia Lewis "Starbucks (HK) Case Note: The Ambiguous Limb of Goodwill and the Tort of Passing Off" (2017) 48 VUWLR 55. 
are not necessarily territorial in the sense of the seller having a physical presence, but buyers in the relevant market will usually suffice in order to show a reputation in that market. ${ }^{42}$

These cases that address reputation and consumer knowledge reflect courts implicitly balancing local economic interests against foreign ones and using mechanisms of territoriality to do so. But there are other policy rationales for creating limits to this exploitation of territoriality. One such limitation the Supreme Court of India expressed as noting that a foreign multinational with no intention of trading in the Indian market should not be able to constrain a local operator who adopted the mark and developed it for the Indian market. ${ }^{43}$

The procedural treaties that have facilitated registration across territorial boundaries are also important for patents. The Patent Cooperation Treaty (PCT) assists patent applicants with obtaining patents in multiple jurisdictions. ${ }^{44}$ The PCT is detailed in its rules and is a significant part of the activities of the World Intellectual Property Organization (WIPO). ${ }^{45}$

WIPO is the international organisation that administers the procedural intellectual property treaties discussed above as well as many substantive agreements. Notably missing from its repertoire, or indeed that of any international organisation, is an agreement about the private international law of intellectual property (jurisdiction over foreign claims and choice of law for such disputes). As noted above, with these matters the territorial rule is applied, but there are inroads to strict territoriality. The English courts have developed a rule that claims of infringement abroad can be brought before them together with local claims for copyright infringement. This approach to jurisdiction has been adopted in New Zealand. ${ }^{46}$ These cases are relatively rare and many of the issues that arise may be settled for the most part. However, the recognition by courts that they can have jurisdiction over foreign copyright infringements is an incursion into the territorial principle.

In the 1990s there was an attempt to overcome the absence of any international agreement on jurisdiction and choice of law in intellectual property infringement cases. The issues were discussed in the drafting of a Convention on International Jurisdiction and Effects of Foreign Judgments in Civil and Commercial Matters. Intellectual property was removed from that Convention because it was so

42 Frankel, above n 5, at [10.1.3].

43 Milment Oftho Indus v Allergan [2004] PTC 585 (Supreme Court of India).

44 Patent Cooperation Treaty 1160 UNTS 231 (signed 19 June 1970, amended 28 September 1979, modified 3 February 1984 and 3 October 2001, entered in force 1 April 2002) [PCT].

45 See WIPO "Patent Cooperation Treaty"<www.wipo.int>.

46 Pearce v Ove Arup Partnership Ltd, above n 5; and Kabushiki Kaisha Sony Computer Entertainment (t/a Sony Computer Entertainment Inc) $v$ Van Veen, above $\mathrm{n} 6$. 
contentious. ${ }^{47}$ Since then the American Law Institute has produced a detailed framework for a potential international agreement on jurisdiction and choice of law and related matters in foreign intellectual property claims. ${ }^{48}$ Also, the Max Planck Group has produced a proposal, ${ }^{49}$ and so has the International Law Association. ${ }^{50}$ As yet, none of these projects have been adopted multilaterally. These are detailed projects which cannot be summarised here. Importantly for present purposes, they recognise that a simplistic approach to territoriality does not necessarily produce good results for enforcement of rights and so, in various ways, these projects recognise the need to overcome territoriality for reasons such as consolidating proceedings in one jurisdiction and applying one law to ubiquitous infringement.

When it comes to pharmaceutical patents the problematic effects, in particular lack of access to medicines, of very strict rules on territoriality were sharply illustrated with the negotiation of compulsory licensing flexibiltites. Under the TRIPS Agreement compulsory licences are rarely available but, in any event, only for supply of the domestic market. ${ }^{51}$ For countries with no manufacturing capacity or ability to pay first world prices, these compulsory licensing provisions were useless. This led to the negotiation of the Doha Declaration on Public Health ${ }^{52}$ and eventually the amendment of the TRIPS Agreement to allow for parallel importation of pharmaceuticals made under compulsory licence in very limited circumstances. ${ }^{53}$ Territoriality has also played a significant role in the limiting the manufacture and supply of COVID-19 vaccines. ${ }^{54}$

\section{THE PROS AND CONS OF TERRITORIALITY}

The territorial approach often conflicts with the realities of trade in intellectual property, both across borders in the traditional sense and on the internet. Licensing rights in several countries is sometimes purportedly done on a global basis, whereas the legal agreements may really be a series of

47 See INTA "Hague Judgment Convention Fails to Include Intellectual Property Provisions" (1 September 2019) <www.inta.org>.

48 Francois Dessemontet, Rochelle Dreyfuss and Jane Ginsburg Intellectual Property Principles Governing Jurisdiction, Choice of Law, and Judgments in Transnational Disputes (American Law Institute, Philadelphia, 2008).

49 European Max Planck Group on Conflict of Laws in Intellectual Property Conflict of Laws in Intellectual Property: The Clip Principles and Commentary (Oxford University Press, Oxford, 2013).

50 ILA Committee on Intellectual Property and Private International Law "Guidelines on Intellectual Property and Private International Law (Kyoto Guidelines)" (2021) 12 JIPITEC 86.

51 TRIPS Agreement, above n 1, art 31(h).

52 The Doha Declaration on the TRIPS Agreement and Public Health WT/MIN(01)/DEC/2, 20 November 2001(Ministerial Conference, Fourth Session).

53 TRIPS Agreement, above n 1, art 31 bis.

54 See Susy Frankel "COVID-19, Vaccines and International Knowledge Governance on Trial" (forthcoming). 
territorial licences. Online infringements can occur anywhere and so the choice of one jurisdiction as the place of infringement can seem arbitrary and will not necessarily address all relevant harms, especially if one place cannot take jurisdiction over all relevant matters. With the internet, the problem of locating the alleged infringement may also raise complications. ${ }^{55}$ These sorts of matters are connected to the issues that form the battleground of how generally to protect intellectual property on the internet, which is a detailed subject. For the purposes of this article, it is important to consider that those who benefit from the territorial operation of intellectual property rules may oppose territoriality when it comes to enforcement (and likely also the payment of tax). As discussed above, by dividing their rights and advantageously exploiting worldwide markets, global intellectual property owners have much to gain. They are often the same actors who would prefer not to have to bring more than one infringement proceeding, relating to the same acts, in more than one jurisdiction and they therefore argue for a more consolidated and less territorial global model of enforcement.

Territoriality, however, can also have advantages for non-rightsholders. Territoriality provides a platform for accommodating competing interests in a domestic policy framework. The minimum standards model leaves space for domestic policy to frame intellectual property norms to reflect the conditions in each country or region, albeit in an international law framework. At a legislative level this means that exceptions, and sometimes more extensive protection, appropriate in one country can be enacted, but if they are not appropriate in another country, the same exceptions need not be enacted there. In the area of patent law, for example, New Zealand has a different experimental use exception from the United States. ${ }^{56}$ This may broadly reflect the two country's different economic positions in regard to innovation activities. Ironically, because of a Supreme Court decision, the United States allows for more parallel importation of patented products than New Zealand does. ${ }^{57}$ When it comes to issues about what are appropriate copyright exceptions in a digital world, New Zealand still retains its own specific regime that incorporates aspects of both its own policy design and some approaches from jurisdictions. ${ }^{58}$

The presence of a Māori trade mark advisory committee and Māori patent advisory committee in New Zealand's intellectual property office is illustrative of the flexibility that a territorial regime can

55 See generally Marketa Trimble "The Multiplicity of Copyright Laws on the Internet" (2015) 25 Fordham Intell Prop, Media \& Ent L J 339.

56 For New Zealand's experimental use exception, see Susy Frankel "An Experimental use Exception for New Zealand" (2009) 17(5) JWIP 446; for the United States, see Rochelle Dreyfuss "Protecting the Public Domain of Science: Has the Time for an Experimental Use Defense Arrived?" (2004) 46 Ariz L Rev 457.

57 Impression Prod v Lexmark Int'l Inc 581 US 1523 (2017), allowing the parallel importation of certain patented ink cartridges into the United States where the owner of the relevant patents was part of the same Lexmark group of companies.

58 See Copyright Act, pt 3. Copyright law is under review to align it better with the digital age. See MBIE "Review of the Copyright Act" (26 February 2021) <www.mbie.govt.nz>. 
bring. These committees aid the operation of provisions that may be used to prevent certain sorts of registrations that conflict with Māori interests. ${ }^{59}$ This is possible because of the territoriality that New Zealand has over such registrations systems.

Without territoriality it would be possible, even if politically challenging, to completely harmonise intellectual property rights into a detailed and prescriptive one-size-fits-all model. Even with countries that have many things in common and a close trading relationship, such as New Zealand and Australia, there are many differences in intellectual property law that have proved difficult to harmonise and so have not been. ${ }^{60}$ The continuing negotiation of international norms in intellectual property often involves attempts to harmonise some details of the law.

Since the formation of the WTO, some nations have increasingly used various bilateral and plurilateral trade agreements (often called free trade agreements) to create more extensive and detailed intellectual property rights. Territoriality supports these fragmented and various agreements, which have proven to be easier to finalise than when there are multiple parties involved. The pressures on small or developing countries in bilateral and plurilateral negotiations is well documented and those fora are used to achieve gains that have not been achieved in multilateral forums. ${ }^{61}$ Even with use of those sort of free trade agreements complete prescriptive harmonisation is unlikely, in part, because in multilateral negotiations, small and developing economies can group together to negotiate more effectively for their interests.

Because of the relationship between economic development and level of intellectual property protection, complete global harmonisation of norms is both undesirable and unlikely. The EU, and its various directives, is the best international model for a type of international harmonisation, but the differing interpretations of those directives across the EU show the difficulty of such an exercise. ${ }^{62}$

It is reasonably uncontroversial that territoriality can produce both desirable and undesirable outcomes. What is more controversial is what is desirable and what is not.

59 See Trade Marks Act 2002, ss 17(1)(b) and 178-179; and Patents Act 2013, s 225 respectively.

60 Susy Frankel and Megan Richardson "Trans-Tasman Intellectual Property Coordination" in Susy Frankel (ed) Learning from the Past, Adapting for the Future: Regulatory Reform in New Zealand (Lexis Nexis, Wellington, 2011) at 527-553; and Susy Frankel and others "The Challenges of Trans-Tasman Intellectual Property Coordination" in Susy Frankel and Deborah Ryder (eds) Recalibrating Behaviour: Smarter Regulation in a Global World (LexisNexis, Wellington, 2013) at 101-138.

61 See for example Susan K Sell "TRIPS Was Never Enough: Vertical Forum Shifting, FTAS, ACTA, and TTP" (2011) 18 J Intell Prop L 447.

62 Catherine Seville "EU Intellectual Property Law: Exercises in Harmonization" in Damian Chalmers and Anthony Arnull (eds) The Oxford Handbook of European Union Law (Oxford University Press, Oxford, 2015); and Justine Pila and Ansgar Ohly (eds) The Europeanization of Intellectual Property Law: Towards a European Legal Methodology (Oxford University Press, Oxford, 2013). 


\section{CONCLUSION}

Territoriality is a pervasive and principal part of the international intellectual property system. It supports the existence of both territorially bound registered and unregistered rights and the enforcement of those rights. Rights owners can choose to use their multiplicity of rights to segment markets internationally, creating a worldwide web of profit generating intellectual property sales and licences. The businesses that reach such a transnational or multinational scale almost certainly do not pay taxes in many parts of the world where they trade. This article highlights how pervasive territoriality is in intellectual property policy and design. While the payment of taxes is driven by tax policy, the ability to skip territorial boundaries with the untaxed profits and royalties earned from territorial intellectual property exploitation is, at that macro-level, a contradiction in international law. 
(2021) 52 VUWLR 